\title{
Alice in WonderlandSyndrome
}

\author{
Síndrome de Alice no País das Maravilhas
}

Wilson Luiz Sanvito ${ }^{1}$

'Associate Professor and Emeritus Professor of Neurology at the Medical Sciences School of Santa Casa in São Paulo. Assistant Étranger of the Paris Medical School.

\section{*Correspondence}

Wilson Luiz Sanvito

E-mail:wsanvito@uol.com.br

Received: June 12, 2019.

Accepted: June 20, 2019.
At the end of my office hours, I saw to a distressed mother. Her 9-year-old daughter presented that day during recess a condition characterized by strange perceptions. She reported seeing huge and deformed people (big noses, crooked mouths, exceedingly long arms...). The manifestation lasted approximately 15 minutes and was followed by facial paleness and an episode of mental confusion, with verbalization of disconnected words and incoherent phrases. Some minutes later, the child became drowsy and fell asleep. When her mother arrived at the school, she was still sleeping. When she woke up, two hours later, she was lucid and reported only feeling a heaviness in her head.

During questioning, the mother informed that since the age of 8 years, her daughter presented headache episodes preceded sometimes by blurry vision. The mother is a migraineur and her own mother, already deceased, was also one. Nothing abnormal was found when examining the minor and I stated to the mother that the episode was probably a migraine, which during childhood can present this kind of manifestation. In face of the unbelief of the mother, I requested a computed tomography of the head and an EEG - both of which did not show abnormalities.

I had the opportunity to followup on this patient over the course of three years. During this time, she presented headache episodes, not all of which were preceded by visual manifestations. In this case, the diagnosis was settled as migraine with aura, consisting of a variant called Alice in Wonderland Syndrome.

Visual auras are the most common and originate from the posterior portion of the brain (occipital lobe). The description of a visual aura is not always easy for the patient. The most detailed and precise descriptions are done through own experience, by either doctors or other healthcare professionals that suffer from this sort of migraine. Data are frequently collected from patients through the anamnesis, in complaints during the crises at emergency services, using questionnaires during interviews, and by analyzing drawings made during the postcritical period. All methods present limitations. Loss of vision in half the visual field (hemianopsia) or in certain points of the visual field (negative scotoma) are common complaints. Scotoma can also be positive and manifest in several ways: focused flashes, colorful circles, the illusion of blinking lights, eye floaters, zigzagging lines, mosaic vision (like a kaleidoscope)... Scotoma can have various colors (gray, red, golden, blue or purple), though the color may not be specific and be more like a very bright white. There is also a form of negative scotoma in which the migraineur sees objects split in half. This condition can either increase in size as the crises evolve or become fragmented into smaller parts.

Auras can be more elaborate and present themselves as distortions of visual figures. These phenomena are more frequent in children and are externalized as perception disorders, which can include various types of body image distortions (macropsias, micropsias, metamorphopsias), feelings of derealization and depersonalization, and changes to their perception of time. This is the Alice in Wonderland syndrome. In this curious syndrome, the patient has the feeling that 
people are either exceedingly large (macropsias) or disproportionally small (micropsias). This inadequacy in size can also be perceived regarding one's own body, such that an individual may feel for example that one of their limbs is gigantic. Other manifestations may occur: distortion of their own body segments (as if looking into a distorting mirror) or of others, feeling of levitation or of a double personality, loss of spatial recognition, etc. Transitory alterations in certain areas of the brain (particularly in parietal lobe areas) seem to be responsible for these described psychosensory abnormalities. Auras are believed to be determined through spreading depression, though it is not clear why extremely elaborate auras - with important perception disorders - are more frequent during childhood. Perhaps the immature brain (not entirely myelinated) can be more vulnerable to a spreading depression event. This type of migraine is more common in children and usually begins around the age of 8 years. The associated manifestations, translated into elaborate auras, usually give way during adolescence.

The Alice in Wonderland syndrome was reported for the first time in 1955 by the English psychiatrist John Todd, who believed the syndrome was related to defects in parts that form the eyes. However, it is known now that the condition occurs due to a neural change in perception that affects vision, feelings, touch and even body image. The condition was initially described as Todd's syndrome, but as a reader and admirer of Lewis Carroll, the psychiatrist proposed the name that established Carroll as an author.

Though this is a polemic discussion, it seems like migraines influenced Lewis Carroll's description of some characters in the book Alice in Wonderland. The Englishman Charles Lutwitge Dodgson (1832-1898) adopted the name Lewis Carroll as a pseudonym to sign his works of fiction (4). This is the explanation. Lewis Carroll was a professor, mathematician, poet, painter, amateur photographer and deacon of the Anglican
Church. He would sign his academic publications (math and logic) with his real name. Carroll was a curious person that did not get along with adults and adored young girls. He dedicated his most successful books to a girl named Alice, daughter of dean Liddell. It seems that Carroll loved Alice deeply, a 10-year-old girl, while he was 32 years old. The author was also an excellent photographer (photography was considered at the time avant-garde art) and enjoyed photographing girls in either revealing clothes or naked $(2,3)$.

Regardless of Carroll's "bilious headaches", detailed records from his diary (collected 20 years after they were reported) demonstrated that he suffered from migraines with aura. However, the book Alice in Wonderland appeared in 1865, which according to scholars researching his biography was before the beginning of his migraines. Nevertheless, the subject is still under discussion, with some believing the author had already experienced previous migraine events.

In conclusion, I must emphasize that the Alice in Wonderland syndrome is not a prerogative to migraine and should be considered as a differential diagnosis for epilepsy, use of hallucinogenic drugs (such as LSD), consumption of hallucinogenic mushrooms, schizophrenia, and brain tumors. The syndrome can also occur during the initial phases of infection by the Epstein-Barr virus in children (1).

\section{REFERENCES}

1. Bolis, V., Karadedos, Ch. et al. - Atypical manifestations of Epstein-Barr virus in children: a diagnostic challenge. J Pediatr (Rio J). 2016; 113-21.

2. Sanvito, W. L. - Alice no país das maravilhas. In O Mau Gênio do Cérebro: O impacto da doença neurológica. A Girafa, São Paulo, 2006, p. 65.

3. Sanvito, W. L. - Síndrome de Alice no país das maravilhas. In Síndromes Neurológicas, Atheneu (4ª edição), Rio de Janeiro, 2019, p. 15.

4. Stoffel, S. L. Lewis Carroll and Alice - New Horizons. Thames and Hudson, London, 1997. 